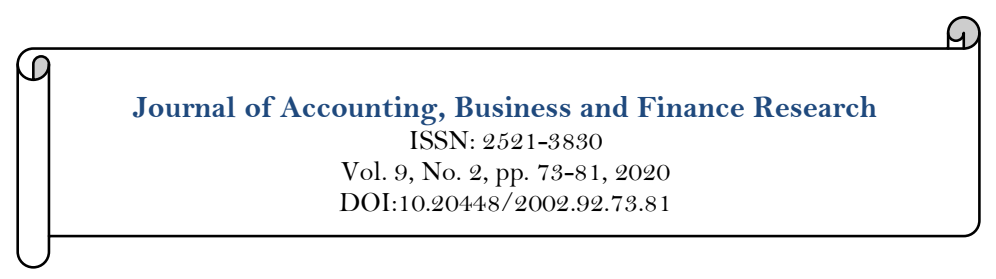

\title{
Fiscal Policy and Stock Market Efficiency in the USA: An ARDL Bounds Testing Approach
}

\section{Michael Anthony Adams}

Tbilisi State University, Georgia.

Email:Michael_A.A@eab.tsu.edu.ge

\begin{tabular}{|c|c|}
\hline Abstract & \\
\hline $\begin{array}{l}\text { The basic aim of this study is to evaluate the market efficiency hypothesis by } \\
\text { using the fiscal policy information implemented in the context of the New } \\
\text { York Stock Exchange. In order to take into account that the macroeconomic } \\
\text { data of a developed country like USA has a limited size and may be } \\
\text { governed by structural breaks and inconsistencies this paper proposed the } \\
\text { adoption of the ARDL bounds testing approaching in order to effectively } \\
\text { evaluate the relationship between the lagged macroeconomic variables and } \\
\text { the stock market returns. Also, the use of this technique allows for the } \\
\text { evaluation of both short run and long run relationships and associations } \\
\text { among the variables. The study uses data from } 2008-2018 \text { to investigate the } \\
\text { efficiency of the stock market. The results suggest that in the long run the } \\
\text { stock prices fully reflect the information issued by the fiscal policy and reflect } \\
\text { on the past activities of the fiscal policy as well. In the short run however, the } \\
\text { New Tork stock exchange index SESP 5oO reacts differently. The NYSE } \\
\text { stock index was found to only efficiently reflect the unexpected news from the } \\
\text { fiscal policy. Moreover, the results also show that the prices in terms of oil, } \\
\text { production and consumer prices were also found to be correlated with the } \\
\text { stock prices. The increase in the consumer prices or inflation and average } \\
\text { economic translates in increased profitability for the firms and the increase in } \\
\text { the oil prices seems to have a negative impact on the firm profitability }\end{array}$ & $\begin{array}{l}\text { Keywords: } \\
\text { ARDL } \\
\text { Stock market } \\
\text { Market efficiency } \\
\text { Fiscal policy } \\
\text { US. } \\
\text { Licensed: } \\
\text { This work is licensed under a } \\
\text { Creative Commons Attribution } 4.0 \\
\text { License. } \\
\text { Publisher: } \\
\text { Scientific Publishing Institute } \\
\text { Received: 27 April } 2020 \\
\text { Revised: } 4 \text { June } 2020 \\
\text { Accepted: } 18 \text { June } 2020 \\
\text { Published: } 16 \text { July } 2020\end{array}$ \\
\hline
\end{tabular}

Funding: This study received no specific financial support.

Competing Interests: The author declares that there are no conflicts of interests regarding the publication of this paper.

\section{Introduction}

Since 1970, the economists have been focusing on efficient marketing due to fiscal policy (FP) (Chugunov \& Pasichnyi, 2018). This policy helps in assuming the prices of the financial assets that reflect the existing information and deliver precise signals for the investors. Stock price (SP) directly influencing the process of determining the fundamental value as it acts as an unbiased estimator, and it can be helpful when the stocks are undervalued or overvalued (Ugwuanyi \& Ugwunta, 2017). The nexus between long-term risk and stock returns is high in a well-organized marketplace, and the stakeholders are not able to earn additional returns unless they take greater risks. The prices highly affect the information that is currently available for the stakeholders in an efficient market, such as the forecasting concerned with the development of several macroeconomic variables (Slepov et al., 2017). The prices of the products and the stock will integrate several changes in the fiscal policy rapidly after the information has become available publicly only if the marketplace is adequate due to FP. The below table enlists the FP of US in recent and present years; 
Table-1. Fiscal policy of US

\begin{tabular}{l|l}
\hline 3 March 2019 & $\begin{array}{l}\text { The debt ceiling is reinstated (mainly after being suspended in } \\
\text { early 2018) }\end{array}$ \\
\hline From August to November 2019 & $\begin{array}{l}\text { It is forecasted that the Treasury will run out of sufficient } \\
\text { liquidity to continue executing the public expenditure. }\end{array}$ \\
\hline 2 November 2019 & $\begin{array}{l}\text { Being the bargaining of the new fiscal year, several items of } \\
\text { expenditure must be passed. }\end{array}$ \\
\hline 2 January 2020 & $\begin{array}{l}\text { The expenditure rule of } 2017 \text { is reinstated, which could mainly } \\
\text { result in a huge decrease in public spending (-100 billion US } \\
\text { dollars). }\end{array}$ \\
\hline
\end{tabular}

The entire appearance and phenomenon of market efficiency and the price have been considerably gaining importance from academic researchers and scholars since the past few decades Seddighi and Yoon (2018) nonetheless, it is can see that even now in a modern and efficient business environment an FP gap exist in market efficiencies as the number of businesses develops effective fiscal policies and procedures (Gupta, Choudhary, \& Agarwal, 2018). Rose, Paparas, Tremma, and Aguiar (2019) suggested that to address and respond to these gaps and limitations pointed out by previous studies, the contextual variables and factors of FP affecting the market price and efficiency need to be evaluated and identified in detail and effective manner. Since the studies and research efforts on the fiscal policy and its impacts on the overall market efficiency are limited and sparse, this study needs to be completed on the markets of the USA (Lin, Chiao, \& Wang, 2019). Therefore, the current research is new and justified in understanding the exclusive impact of FP on market efficiency in the context of USA markets. Moreover, the market efficiency of the USA also highlighted in the form of a graph of the different period (Figure 1)

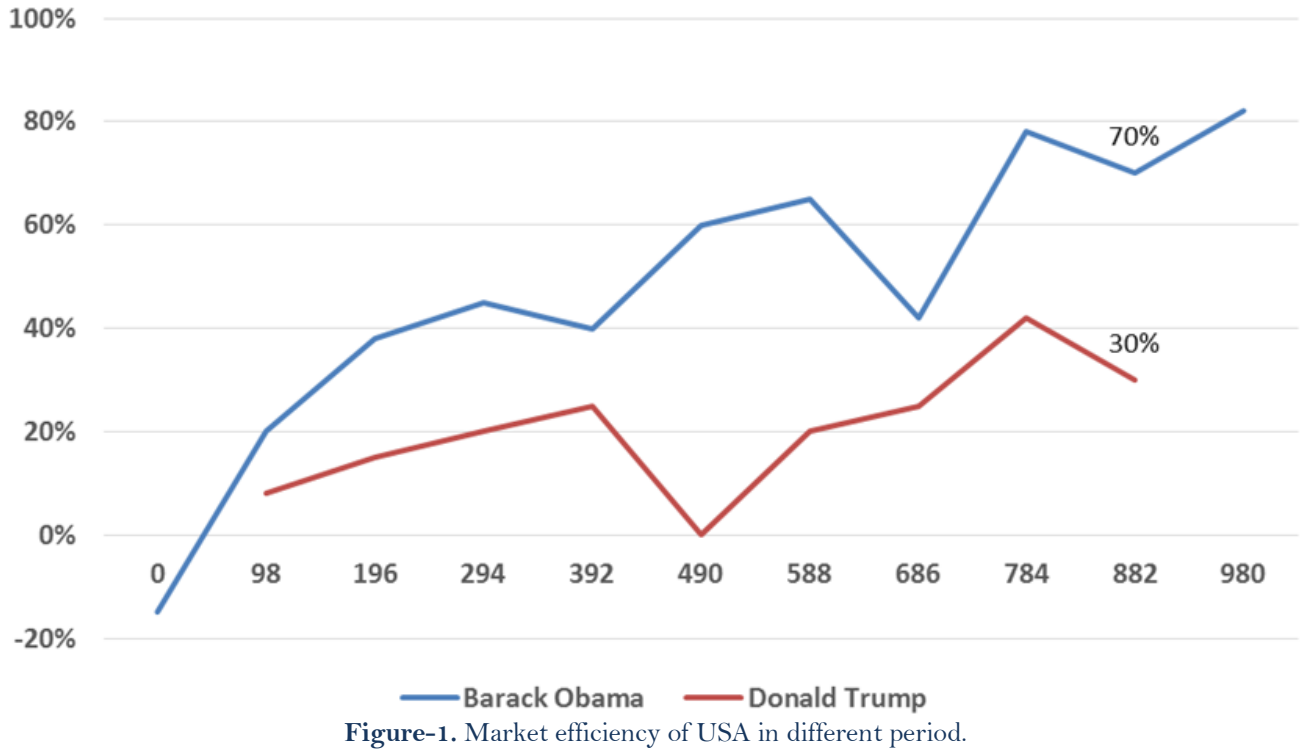

Depend on the above justification statement the major target of the current research is to analyze the overall impact of FP and procedures of government on the SM price and efficiency in the context of the USA. Another objective of the given study is to evaluate the semi-strong type of market capability arguments and discussion with the respect to FP information, in the context of USA markets. Considering macro-economic data series of several emerging and growing nations generally have a restricted volume and also may be afflicted mainly by several structural breaks and inconsistencies, the given research study suggests bounds testing concept majorly for evaluating the nexus between stock returns (SR) and slow macro-economic factors.

Like any other past studies and researches, the given research effort has profound and supportive advantages to practice and theory. Practically, the given paper proves to be very fruitful for academic scholars and practitioners and the market policy and FP makers who must develop and frame FP and procedures according to the needs of the market. Theoretically, the following research effort contributes positively to the current section of data and information on these above factors and variables.

The rest of the thesis is framed as follows: section second literature reviews and reflections both the empirical and theoretical literature determining the connection and interdependence between FP and the stock market (SM) efficiencies and prices; section third presents the overall dataset as well as the methodology incorporated by the given research effort; section four mainly gives the analysis and estimates of the bonds testing practice and approach and then discusses the outcomes and findings in detail; section five mainly framed to extends the evaluation majorly by researching the influences of likely and unlikely modifications in 
FP on SM returns, while seeing certain stability checks and tests suggested in the study literature; section six majorly framed to presents the concluding and final opinions, also give certain policy as well as managerial applications of the present research and also develop policy suggestions that help market experts and future scholars.

\section{Literature Review}

\subsection{The Theory of Stock Market Efficiency}

In developing countries, from the beginning of the transition process, the European countries have made great progress in the capital as well as stock markets (Ali, Shahzad, Raza, \& Al-Yahyaee, 2018). Commonly, some various theories and models support the stock market performance and policy measures. However, the theory of SM efficiency is one of the important theories that have provided the source of financing, investment opportunities for economic subjects. The theory of stock market efficiency was introduced by an economist 'Eugene Fama' in a term paper first time in 1970 (Ayodele \& Maxwell, 2017). According to Fama, the theory of stock market efficiency provide all relevant details and information to other party either it is government, investor, companies, or individuals. When markets are efficient, it provides all present, similar information and when markets are inefficient, then all data used into prices and so there is no method to weary the market (Syed \& Bajwa, 2018). Moreover, the theory given by the Fama has also illustrated that the development of a market also influenced by the expansionary economic policies of a country which are known as fiscal and monetary policies.

As, according to this theory the, expansionary economic policy is more effective and produces efficient results than fiscal policy (Al-Khazali \& Mirzaei, 2017). The expansionary policy helps to increase the stock market performance because it leads to generate economic activities. On the other hand, the fiscal expansionary policy in an economy also helps to increase the aggregate demand as well as the employment level. The higher is the aggregate demand, the more it generates employment opportunities (Rösch, Subrahmanyam, \& Van Dijk, 2017). Besides, Fama has presented the three degrees of market efficiency theory and the weakest form of market efficiency is the past price movements that help to form the future predictive prices. While the second degree of the theory is the semi-strong market competence in which the stock prices reflect all relevant and available knowledge in a sequential form. In which all people and individuals have asymmetric information contained in historical as well as the present form of prices (Angelovska, 2018). The last degree of the theory of SM capability is the strong form of tests in the information which is provided is regarded as private information among all other forms of information. The theory of stock market efficiency also based on the number of assumptions that are made about securities, bonds, and how they function (Stakić, Jovancai, \& Kapor, 2016). Therefore, the theory is highly related to economic policies, measures, and market hypothesis.

\subsection{The Relationship between Fiscal Policy and Stock Market Price/Efficiency}

The given research acknowledges the appearance of expanded literature that has indicated empirical proof on the overall influence of FP on market efficiency (ME) and price in general. The present paper further gives a brief introduction of the most concerning efforts and researches over the last few years, Stoian and Iorgulescu (2020) through an empirical approach, rational-demands macro framework and open type of economy indicated that spending improves as well as tax cuts derive economic environment, still that the consequence of encouragement is mainly affected by markets. Prior studies and efforts also state that expectations of significant deficit majorly lead to an improvement in the future ST and present LT interest rates, which generally minimizes investments and other several interest associated costs.

However, in economics and market settings, fiscal policy and rules are the adoptions of government earnings collection such as taxes and other and spending to impact the nation's stock market. According to Mbanga and Darrat (2016) the use of government revenues as well as expenditures to affect macro-economic factors generated as a consequence of the depression majorly when the past approaches to market became unfamiliar. Prukumpai and Sethapramote (2019) in his research described that FP is mainly based on different economic theories and models that speculate that national administration modifications in the equate of tariff and also SP impacts aggregate need and the degree of market action (Ito, Noda, \& Wada, 2016). A study by Thanh, Thuy, Anh, Do Thi, and Truong (2017) states that FP is the key strategy and processes used by a region central administration to impetus its fiscal aims and purpose and according to this directly influence the level of SM efficiency. Moreover, the collection of these strategies and policies enables these authorities and economic experts to target inflation and to improve the degree of investment in the country through directly affecting the market prices and efficiencies. Additionally, FP is majorly designed to try to keep overall GDP growth at a significant level and investment rate near the natural rate of development (Khan, Nawaz, \& Hussain, 2011; Li, Zha, Zhang, \& Zhou, 2018). The overall above discussion implies that FP is mainly used to stabilize the market and economy of the country throughout the business period. Anghelache, Jakova, and Oanea (2016) discovered that modifications in the degree and composition of taxation and government spending can directly affect macro-economic factors and variables like aggregate demand, investment, income distribution, and allocation of resources. FP can mainly be illustrious from MP and procedures, in that FP 
directly deals with tariff and GS which according to Lawal, Somoye, Babajide, and Nwanji (2018) impact stock market returns and FP is mainly controlled by central authorities, while MP majorly deals with the capital supply and IRs and is generally controlled and managed by the central bank, and according to both FP and MP affect a region's fiscal and market performance and efficiency. According to Tu and Wang (2020) governments use FP to impact the degree of aggregate needs in the overall economy of the country, so that some economic objectives can be attainted such as market price stability and economic development. A study by Lawal, Nwanji, Adama, and Otekunrin (2018) suggests that improving GS and minimizing the degree of tariffs are the direct process to control market efficiency and price, stimulate it, while according to $\mathrm{Hu}$, Han, and Zhang (2018) minimizing allocating and improving taxes mainly after the economic development. Furthermore, Suhaibu, Harvey, and Amidu (2017) argue that expansionary FP should mainly be used by the government in times of recession or insignificant market activity as an effective and essential instrument for developing the framework for significant and stable market growth and working towards full investment. From the classical perspective, expansionary fiscal policy (EFP) also minimizes net exports, which has according to Gorton, Huang, and Kang (2017) a mitigating impact on national output as well as market price and income (Yu, Fang, \& Sun, 2018). This is mainly because, all other factors being equal, the bonds issued from a state executing expansionary FP now offer a significant RoR. In other sense, firms and investors must content with their authority for money thus they attempt significant RoR.

The overall influence of FP on SM efficiencies has been significantly researched since the past few years considered the bi-indicator connections between the actual economy and the financial industry of the nation. In a simplified approach, he indicates how FP can mainly impact asset and labor chain that further impact wages, and prices, acquiring a positive influence on the FA businesses. Canh (2018) significantly improve the current body of knowledge and demonstrate how economic modifications and policies can impact SR, and he also indicates that an EFP that majorly have to improve profit and IRs has equivocal impacts on the SM of the country, which drops according to Kotha and Sahu (2016) in the case of unfavorable conditions and news and improves mainly due to favorable conditions and news. Thus, the given research paper proposes the following hypothesis;

H1: There is a direct and positive nexus between fiscal policy and market price and efficiency.

\section{Methodology}

3.1. Data and Variables

The main focus of this study is to evaluate whether or not the NYSE (New York stock exchange) prices of the stocks fully reflect the information of the fiscal policy and therefore we analyze the efficiency of the market of the US. The fiscal policy information is being evaluated on the basis of the overall balance to the budget ratio and the movement of the NYSE stock prices is being evaluated on the basis of the logarithm of the NYSE index S\&P 500.As per the theoretical conclusions provided through the studies of Tobin (1969) and Blanchard (1984) the monetary policy is also introduced as an explanatory variable. The Federal Reserve's interventions in the money supply are influenced by the short term rates of the interest. Thus, the monetary policy is being evaluated on the basis of the short term interest rate. The macroeconomic studies (Clare \& Thomas, 1994; Flannery \& Protopapadakis, 2002) have suggested some other factors for the evaluation of the stock prices as well. Thus, the explanatory variables include inflation which is being evaluated on the basis of the logarithm of the CPI, the influence of the general economic conditions measured through the industrial production index and the impact of the input costs, evaluated on the basis of the logarithm of the oil prices. Yearly data from the period ranging 2006-2018 has been considered for the purpose of this study. The data has been collected from the NYSE, Federal Reserve and WDI databases.

\subsection{Model}

In order to evaluate the efficiency of the stock market we need to evaluate whether the past fiscal policy extends impact upon the stock prices. The method of analyzing this impact is to evaluate the impact of the lagged overall budget balance to GDP ratio on the current returns of the stock market. For this purpose, the ARDL bounds testing approach mechanized by Pesaran, Shin, and Smith (2001) is being applied. This method has several advantages. First of all, it is capable of employing variables which have either zero order or first order stationarity, relaxing the requirement that the series should be stationary in all levels. Secondly, its allowance of lagged specifications is suited for the evaluation of impact of past values of the explanatory variables on the current values of the dependent variable. Lastly, it also to evaluate the long run and short run relationships among the variables. Thus, the following model is specified;

$$
\Delta y_{t}=C_{0}+C_{1} t+C_{2} D-\alpha\left(y_{t-1}-\theta x_{t-1}\right)+\sum_{i=1}^{n} \varphi_{y i} \Delta y_{t-i}+\omega \Delta x_{t}+\sum_{j=1}^{m} \varphi_{x j} \Delta x_{t-i}+u_{t}
$$

In the above equation the dependent variable $\Delta y_{t}$ is represented through the returns of the stock market calculated as the change in the stock market index y. The explanatory variables are denoted by the vector xand consist of the budget balance to GDP ratio, the logarithm of consumer price index, the oil prices, the industrial production and the short term interest rate. The term $-\alpha$ accounts for the negative magnitude of 
adjustment coefficient and it evaluates the deviation of the dependent variable from the equilibrium. The terms $\omega_{s} \varphi_{y i}, \varphi_{x j}$ are the short run coefficients which will be evaluating the relationships and fluctuations that aren't based upon the deviations from the equilibrium position. The terms $\mathrm{c}_{0}, \mathrm{c}_{1}$, and $\mathrm{c}_{2}$ are the other coefficients adjusted in the model and the term $u_{t}$ is the error term. The dataset is already small therefore it wasn't possible to incorporate a dummy variable for each of the structural breaks that might be evaluated in the model as it would have severely affected the degrees of freedom of the base model. Thus, only one dummy variable has been introduced to account for the disruptions that might exist in the data series.

\subsection{Unit Root Test}

The unit root test is a major part of the ARDL methodology; thus, the formal analysis begins by the computation of the stationarity status of the variables. Taking the time period under consideration, as it includes of the global financial crisis and the economic crisis that resulted as a by-product of the crisis some time series disruptions are expected to be present in the data. Therefore, the data stationarity is evaluated while considering the presence of structural breaks. The unit root test proposed by Clemente, Montañés, and Reyes (1998) allows for either one or two structural breaks to be present and thus it is used. This method and test also evaluate for the presence of unknown breakpoints in the data. The CMR test authenticates the existence if an additive outlier which is used to capture the change in the time series data due to some type of transitory shock and the innovative outlier as well which accounts for the gradual change in the time series. This study uses the IO model considering the persistence of the shocks that have influenced the values of the variables.

\section{Results}

\subsection{Unit Root Test}

The results of the CMR unit root test are reported in Table 1. It can be seen from the results that the null hypothesis will be rejected, and the alternate hypothesis is accepted as the t-statistics are greater than the critical values. Moreover, the CMR test results indicate that the CPI and IPI are stationary in their log levels whereas the stock market index, the balance to budget, the interest rate and the oil prices are stationary at the first difference, indicated by the letter D in the table. Moreover, the CMR test identifies important structural breaks, majority of which occurred during or around the years to 2008, indicating the impact of the global financial crisis on the dataset.

Table-2. CMR unit root test.

\begin{tabular}{|c|c|c|c|c|}
\hline Variable & Lags & Breakpoints & T-Statistic & Critical Value \\
\hline \multirow[t]{2}{*}{$\mathrm{S} \& \mathrm{P}$} & $\mathrm{O}$ & 2009 & -2.064 & -5.48 \\
\hline & & 2013 & & \\
\hline \multirow[t]{2}{*}{ D_S\&P } & $\mathrm{O}$ & $2008 * * *$ & -7.3 & -5.48 \\
\hline & & 2009*** & & \\
\hline \multirow{2}{*}{ Balance } & 3 & $2008^{* * * *}$ & -4.19 & -5.48 \\
\hline & & $2010^{* * * *}$ & & \\
\hline \multirow[t]{2}{*}{ D_Balance } & 2 & $2010^{* * * *}$ & -12.828 & -5.48 \\
\hline & & $2011^{* * * *}$ & & \\
\hline \multirow{2}{*}{ Interest } & $\mathrm{O}$ & $2017^{* * * *}$ & -3.427 & -4.3 \\
\hline & & $2008 * * *$ & & \\
\hline D-Interest & $\mathrm{O}$ & $2009 * * *$ & -7.089 & -5.48 \\
\hline CPI & $\mathrm{O}$ & $2012^{* *}$ & -5.96 & -4.3 \\
\hline \multirow{2}{*}{ IPI } & $\mathrm{O}$ & $2008^{* * * *}$ & -10.45 & -5.48 \\
\hline & & $2008^{* * * *}$ & & \\
\hline \multirow[t]{2}{*}{ Oil } & 1 & $2010 * * *$ & -4.971 & -5.48 \\
\hline & & $2014^{* * * *}$ & & \\
\hline \multirow[t]{2}{*}{ D_Oil } & $\mathrm{O}$ & 2008 & -7.467 & -5.48 \\
\hline & & 2015 & & \\
\hline
\end{tabular}

\subsection{Long Run Effects}

The Table 2 reports the results of the bounds test, as the F-statistic of the test is significantly greater than the 1 percent upper bound value, therefore the null hypothesis rejecting long run relationships is rejected and the alternate hypothesis is accepted. The model showcases a long-term equilibrium association to be present among its variables. Moreover, the CUSUM and CUSUMSQ tesy evaluative results also indicate that the critical bounds lie in between the $5 \%$ critical bounds indicating that the estimated coefficients' stability. 
Table-3. Bounds test.

\begin{tabular}{c|c|c|c|c}
\hline Test Statistic & Value & Signif. & I(0) & I(1) \\
\hline F-statistic & & & Asymptotic: $\mathrm{n}=1000$ & 2.64 \\
\hline K & 6.561452 & $10 \%$ & 3.2 & 3.34 \\
\hline Actual Sample Size & 2 & $5 \%$ & 4.11 & 3.85 \\
\hline CUSUM & 45 & $1 \%$ & Finite Sample: $\mathrm{n}=45$ & 5 \\
\hline CUSUMSQ & & & 2.768 & 3.53 \\
\hline
\end{tabular}

The results of the long run ARDL estimation are presented in Table 3. As the reliability and validity of the ARDL model has been proven we can evaluate the relationship between the stock market prices and fiscal policy. The lagged budget balance displays a positive impact on the returns of the stock market. Thus, an increase in the balance of the budget, showing either the increase of surplus or reductions of the deficit will lead towards an increasing return period from the stock market. However, the coefficient is insignificant, suggesting that the fiscal policy information has been already reflected in the prices of the stock market and thus the market prices are no longer affected due to the fluctuations in the fiscal policy. Thus, it can be stated that the long run fiscal information is efficiently exhibited by the prices of the American stock market. The impact of the monetary policy (evaluated through the interest rate) and the stock prices, the results insinuate the presence of a significant relationship to be present. Thus, the stock prices will increase in response to the increase of the short term interest rate. The consumer price index and the industrial price index showcase a positive long run association with the stock market. The CPI serves as a proxy for inflation; thus, it is evaluated than an increase in the inflation or the consumer prices would also correlate directly with increasing stock returns. The positive association among the production and returns of the stock market show that an increase in the average economic output, which is an indication of intensified economic productivity and activity, leads to higher earnings for the firms. The lagged oil price has a negative effect on the stock market returns, however the estimated coefficient is significant at the 5 percent level. An increase in the oil prices will eventually lead towards the cost of production and thus will influence a negative impact upon the profitability of the firms.

Table-4. Long Run estimation.

\begin{tabular}{c|c|c|c}
\hline \multicolumn{5}{c}{ ARDL Long Run Form } \\
\hline Selected Model: ARDL(1, O, 1) \\
\hline Variable & Coefficient & Std. Error & t-Statistic \\
\hline balance(-1) & 0.02018 & 0.015209 & 1.3264 \\
\hline interest(-1) & $0.025425^{* *}$ & 0.011863 & 2.14382 \\
\hline CPI $(-1)$ & 4.126314 & 2.979871 & 1.384724 \\
\hline IPI $(-1)$ & 2.024075 & 1.208901 & 1.674316 \\
\hline Oil $(-1)$ & $-0.135551^{* *}$ & 0.054949 & -2.46707 \\
\hline
\end{tabular}

\subsection{Short Run Evaluations}

The results of the short run evaluation have been presented in Table 4. The short run changes in the fiscal policy have a significant and positive impact on the returns of the stock market. The joint impact of the lagged variables is evaluated through the Wald test. The chi square value and the probability of the test reveal that the null hypothesis stating the zero value of all summed coefficients is accepted. As the aggregate impact of the previous implemented fiscal policy is insignificant, we conclude that in the short run there is an evidence of the efficiency of the American stock market. The impact on the monetary policy, evaluated through the lagged and current changes in the interest rate in the short run, a negative and insignificant relationship is discovered. The short run correlations among the consumer prices and the stock prices reveal that an increase in the prices in the short run will influence increased profitability for the firms. The short run impact of the IPI is insignificant though positive (Table 5). The resultant impact of the oil prices is negative and significant in the current state, the lagged coefficients are insignificant. The error correction term is lagged, and its coefficient is negative and significant at the 1 percent level, therefore, confirming the presence of a strong corrective mechanism to be present in case of deviations. 
Table-5. Short Run estimation.

\begin{tabular}{|c|c|c|c|}
\hline \multicolumn{3}{|c|}{ Method: ARDL (Short Run) } & \multirow[b]{3}{*}{ t-Statistic } \\
\hline \multicolumn{3}{|c|}{ Selected Model: ARDL $(1,0,1)$} & \\
\hline Variable & Coefficient & Std. Error & \\
\hline D_Balance & $0.028861^{* * * *}$ & 0.008328 & 3.478990 \\
\hline D_Balance(-1) & 0.015127 & 0.012088 & 1.335269 \\
\hline D_Balance(-2) & 0.017125 & 0.010421 & 1.547429 \\
\hline D_Interest & $-0.054355^{* * * *}$ & 0.010455 & -5.227137 \\
\hline D_Interest(-1) & $-0.042227 * * *$ & 0.014644 & -2.889750 \\
\hline D_Interest(-2) & $-0.029321^{* * *}$ & 0.013998 & -2.101631 \\
\hline D_CPI & $3.428114^{*}$ & 1.984051 & 1.727875 \\
\hline D_IPI & 0.332223 & 0.781001 & 0.425616 \\
\hline D_Oil & $-0.317057^{*} *$ & 0.119647 & -2.649827 \\
\hline D_Oil(-1) & 0.105806 & 0.095352 & 1.110704 \\
\hline D_Oil(-2) & 0.159972 & 0.101542 & 1.574428 \\
\hline R-squared & 0.89 & F-statistic & 6.561452 \\
\hline Adjusted R-squared & 0.86 & Prob(F-statistic) & 0.005 \\
\hline Akaike info criterion & 6.489556 & $\operatorname{ECT}(-1)$ & $-0.797446^{* * *}$ \\
\hline Jarque Bera & 1.6742 & Schwarz criterion & $2.8602^{* *}$ \\
\hline Probability JB & 0.4329 & Linear Trend & $0.022052^{*} *$ \\
\hline Wald Test & 3.005 & & \\
\hline
\end{tabular}

\section{Discussion}

Several research studies have been carried out to predict the changes of the fiscal policy through existing fiscal lags. The study by Blanchard (1984) initially drew attention to the presence of the lag between the enactment of a fiscal measure and moment at which its resultant effects are translated in the economy. The study by Leeper, Walker, and Yang (2013) and Leeper, Richter, and Walker (2012) focused upon the legislative lag between the proposal of a fiscal measure, its enforcement and approval dimensions. The study by Gupta., Jalles, Mulas-Granados, and Schena (2017) focused upon the emphasis of the fiscal gap that occurs between the adjustment and consolidation period. These periods lead towards uncertainty among the agents of the economy, a reduction in the governmental confidence and an increase in the intertest rates of the government. Thus most of the fiscal changes are known in advance and therefore can be adjusted in the stock markets giving an indication of weak form efficiency. The study by Stoian and Iorgulescu (2020) evaluated the significance of the relationships of the fiscal policy and stock market efficiency through an ARDL testing approach. The data from 45 firms following the quarterly results from 2008-2018 quarters was evaluated for the stock market of Russia. The results of the study indicated that the efficient market hypothesis was rejected. The prime reason for this evaluation was that significant impacts of the previous fiscal policy activities were found to have association to the stock market prices. Kuncoro (2017) in a study also evaluated the impact of the stock market volatility and the fiscal policies. The results of the study indicated that with the increase in the investor knowledge more people are beginning to understand and consider the news relating to the fiscal policies for formulation their decisions. The study by Mbanga and Darrat (2016) evaluated the long run and short run effects of the monetary and fiscal policies on the returns of the stock market and evaluated the efficiency of the of the market. The results indicated the presence of a long run equilibrium relation present among the fiscal policy and the stock prices. Moreover, the study found fiscal policy to be the main force behind the overall relation of the stock market. The estimations of the error correction model also validate the presence of the short run associations among the fiscal policy and the stock market prices.

\section{Conclusion}

This study evaluated the relationship between the stock market prices and the fiscal policy reflection, while also evaluating the efficiency of the market. For this purpose, the S\&P 500 index from NYSE was used as it is the largest stock exchange of the country. The fiscal policy determinants were considered to be the balance to budget ratio, the inflation proxied through CPI, output of the country proxied through IPI and the oil prices. In order to evaluate the association among the variables an ARDL bounds testing model was used. The results from the bounds co-integration found the long run relationship to be present among the variables, as the F-statistic was significant. The results indicate that the important effects of the fiscal policy, like changes in inflation rate, increase in the productivity, increased or decreased oil prices are efficiently reflected in the stock market.

The study also has important implications and some limitations. The literature on the evaluation of the macroeconomic indicators and its linkage to the efficiency of the market is relatively limited, thus an important 
theoretical contribution has been made. The researchers and other academicians can utilize this paper to understand the relevance between the efficiency of the stock market and the fiscal policy factors. Moreover, the analysis of the long run and short run effects of the fiscal policy on the stock prices, it can be stated that the effect of the fiscal policy can be transmitted through the stock market to the real economy. The limitations of this study are that a small sample has been used. The data from only 10 years has been used there is a need to diversify the sample. Moreover, this study found that a significant impact of the previous fiscal policy actions and the current stock market prices disputed the presence of market efficiency, a future study focusing on this horizon will aid in the evaluation and understanding of the relation between stock market, market efficiency and fiscal policy actions.

\section{References}

Al-Khazali, O., \& Mirzaei, A. (2017). Stock market anomalies, market efficiency and the adaptive market hypothesis: Evidence from Islamic stock indices. Journal of International Financial Markets, Institutions and Money, 51, 190208.Available at: https://doi.org/10.1016/j.intfin.2017.10.001.

Ali, S., Shahzad, S. J. H., Raza, N., \& Al-Yahyaee, K. H. (2018). Stock market efficiency: A comparative analysis of Islamic and conventional stock markets. Physica A: Statistical Mechanics and Its Applications, 503, 139-153.Available at: https://doi.org/10.1016/j.physa.2018.02.169.

Angelovska, J. (2018). Testing weak form of stock market efficiency at the Macedonian stock exchange. UTMS Journal of Economics, 9(2), 133-144.

Anghelache, G.-V., Jakova, S., \& Oanea, D.-C. (2016). Fiscal policy and capital market performance: Evidence from EU countries from central and eastern Europe. International Journal of Academic Research in Accounting, Finance and Management Sciences, 6(2), 34-43.Available at: https://doi.org/10.6007/ijarafms/v6-i2/2037.

Ayodele, A. J., \& Maxwell, O. O. (2017). Test of the semi-strong efficiency theory in the Nigerian stock market: An empirical analysis. Journal of Finance and Accounting, 5(4), 139-146.Available at: https://doi.org/10.11648/j.jfa.20170504.13.

Blanchard, O. J. (1984). Current and anticipated deficits, interest rates and economic activity. European Economic Review, 25(1), 7-27.Available at: https://doi.org/10.1016/0014-2921(84)90067-9.

Canh, N. P. (2018). The effectiveness of fiscal policy: Contributions from institutions and external debts. Journal of Asian Business and Economic Studies, 25(1), 50-66.Available at: https://doi.org/10.1 108/JABES-05-2018-0009.

Chugunov, I. Y., \& Pasichnyi, M. (2018). Fiscal policy for economic development. Scientific Bulletin of Polissia, 1(1), 54-61.

Clare, A. D., \& Thomas, S. H. (1994). Macroeconomic factors, the APT and the UK stockmarket. Journal of Business Finance $\Theta^{\circ}$ Accounting, 21(3), 309-330.Available at: https://doi.org/10.1111/j.1468-5957.1994.tbo0322.x.

Clemente, J., Montañés, A., \& Reyes, M. (1998). Testing for a unit root in variables with a double change in the mean. Economics Letters, 59(2), 175-182.Available at: https://doi.org/10.1016/s0165-1765(98)00052-4.

Flannery, M. J., \& Protopapadakis, A. A. (2002). Macroeconomic factors do influence aggregate stock returns. The Review of Financial Studies, 15(3), 75 1-782.Available at: https://doi.org/10.1093/rfs/15.3.751.

Gorton, G. B., Huang, L., \& Kang, Q. (2017). The limitations of stock market efficiency: Price informativeness and CEO turnover. Review of Finance, 21(1), 153-200.Available at: https://doi.org/10.1093/rof/rfwo08.

Gupta, S., Choudhary, H., \& Agarwal, D. (2018). An empirical analysis of market efficiency and price discovery in Indian commodity market. Global Business Review, 19(3), 771-789.Available at: https://doi.org/10.1177/0972150917713882.

Gupta., M. S., Jalles, J. T., Mulas-Granados, M. C., \& Schena, M. (2017). Governments and promised fiscal consolidations: Do they mean what they say? : International Monetary Fund.

Hu, L., Han, J., \& Zhang, Q. (2018). The impact of monetary and fiscal policy shocks on stock markets: Evidence from China. Emerging Markets Finance and Trade, 54(8), 1856-1871.Available at: https://doi.org/10.1080/1540496x.2018.1425610.

Ito, M., Noda, A., \& Wada, T. (2016). The evolution of stock market efficiency in the US: A non-Bayesian time-varying model approach. Applied Economics, 48(7), 621-635.Available at: https://doi.org/10.1080/00036846.2015.1083532.

Khan, R. E. A., Nawaz, M. A., \& Hussain, A. (2011). Impact evaluation of structural adjustment program: A case of Pakistan. European Journal of Economics, Finance and Administrative Sciences, 29 (3), 115-120.

Kotha, K. K., \& Sahu, B. (2016). Macroeconomic factors and the Indian stock market: Exploring long and short run relationships. International Journal of Economics and Financial Issues, 6(3), 1081-1091.

Kuncoro, H. (2017). Fiscal policy and stock market returns volatility: The case of Indonesia. International Journal of Economic Policy in Emerging Economies, 1O(2), 153-170.Available at: https://doi.org/10.1504/ijepee.2017.10006012.

Lawal, A. I., Nwanji, T. I., Adama, I. J., \& Otekunrin, A. O. (2018). Examining the Nigerian stock market efficiency: Empirical evidence from wavelet unit root test approach. Journal of Applied Economic Sciences, 12 (2), 53-67.

Lawal, A. I., Somoye, R. O., Babajide, A. A., \& Nwanji, T. I. (2018). The effect of fiscal and monetary policies interaction on stock market performance: Evidence from Nigeria. Future Business Journal, 4(1), 16-33.Available at: https://doi.org/10.1016/j.fbj.2017.11.004.

Leeper, E. M., Richter, A. W., \& Walker, T. B. (2012). Quantitative effects of fiscal foresight. American Economic Journal: Economic Policy, 4(2), 115-144.Available at: https://doi.org/10.1257/pol.4.2.115.

Leeper, E. M., Walker, T. B., \& Yang, S.-C. S. (2013). Fiscal foresight and information flows. Econometrica, 81(3), 11151145.Available at: https://doi.org/10.3982/ecta8337.

Li, E. X., Zha, T. A., Zhang, J., \& Zhou, H. (2018). Active monetary or fiscal policy and stock-bond correlation. Available at SSRN 3106141 . 
Lin, C.-F., Chiao, C.-H., \& Wang, B. (2019). The impact of post-trade transparency on price efficiency and price discovery: Evidence from the Taiwan stock exchange. Managerial Finance, 45(8), 1062-1075.Available at: https://doi.org/10.1108/mf-05-2018-0217.

Mbanga, C. L., \& Darrat, A. F. (2016). Fiscal policy and the US stock market. Review of Quantitative Finance and Accounting, 47(4), 987-1002.Available at: https://doi.org/10.1007/s11156-015-0528-y.

Pesaran, M. H., Shin, Y., \& Smith, R. J. (2001). Bounds testing approaches to the analysis of level relationships. Journal of Applied Econometrics, 16(3), 289-326.Available at: https://doi.org/10.1002/jae.616.

Prukumpai, S., \& Sethapramote, Y. (2019). How does the Thai stock market respond to monetary and fiscal policyshocks? DLSU Business \& Economics Revierw, 28(2), 52-68.

Rösch, D. M., Subrahmanyam, A., \& Van Dijk, M. A. (2017). The dynamics of market efficiency. The Review of Financial Studies, 30(4), 1151-1187.

Rose, H., Paparas, D., Tremma, O., \& Aguiar, L. K. D. (2019). Price transmission: The case of the UK and the USA broiler markets. International Journal of Agricultural Resources, Governance and Ecology, 15(4), 281-306.Available at: https://doi.org/10.1504/ijarge.2019.10025849.

Seddighi, H., \& Yoon, I.-H. (2018). Stock market efficiency and price limits: Evidence from Korea's recent expansion of price limits. Asian Journal of Economics and Empirical Research, 5(2), 191-200.Available at: https://doi.org/10.20448/journal.501.2018.52.191.200.

Slepov, V., Burlachkov, V., Danko, T., Kosov, M., Volkov, I., Ivolgina, N., \& Sekerin, V. (2017). Model for integrating monetary and fiscal policies to stimulate economic growth and sustainable debt dynamics. European Research Studies Journal, 20(4A), 457-470.Available at: https://doi.org/10.35808/ersj/847.

Stakić, N., Jovancai, A., \& Kapor, P. (2016). The efficiency of the stock market in Serbia. Journal of Policy Modeling, 38(1), 156-165.Available at: https://doi.org/10.1016/j.jpolmod.2015.12.001.

Stoian, A., \& Iorgulescu, F. (2020). Fiscal policy and stock market efficiency: An ARDL Bounds Testing approach. Economic Modelling, 90, 406-416.Available at: https://doi.org/10.1016/j.econmod.2019.12.023.

Suhaibu, I., Harvey, S. K., \& Amidu, M. (2017). The impact of monetary policy on stock market performance: Evidence from twelve (12) African countries. Research in International Business and Finance, 42, 1372-1382.Available at: https://doi.org/10.1016/j.ribaf.2017.07.075.

Syed, A. M., \& Bajwa, I. A. (2018). Earnings announcements, stock price reaction and market efficiency-the case of Saudi Arabia. International Journal of Islamic and Middle Eastern Finance and Management, 11(3), 416-431.Available at: https://doi.org/10.1108/imefm-02-2017-0044.

Thanh, T. T. T., Thuy, L. P., Anh, T. N., Do Thi, T., \& Truong, T. T. H. (2017). Empirical test on impact of monetary policy and fiscal policy on Vietnam stock market. International Journal of Financial Research, 8(2), 135-144.

Tobin, J. (1969). A general equilibrium approach to monetary theory. Journal of Money, Credit and Banking, 1(1), 1529.Available at: https://doi.org/10.2307/1991374.

Tu, Y., \& Wang, Y. (2020). Adaptive estimation of heteroskedastic functional-coefficient regressions with an application to fiscal policy evaluation on asset markets. Econometric Reviews, 39(3), 299-318.

Ugwuanyi, U. B., \& Ugwunta, O. D. (2017). fiscal policy and economic growth: An examination of selected countries in Sub-Saharan Africa. International Journal of Academic Research in Accounting, Finance and Management Sciences, 7(1), 117-130.Available at: https://doi.org/10.6007/ijarafms/v7-i1/2587.

Yu, H., Fang, L., \& Sun, W. (2018). Forecasting performance of global economic policy uncertainty for volatility of Chinese stock market. Physica A: Statistical Mechanics and Its Applications, 505, 931-940.Available at: https://doi.org/10.1016/j.physa.2018.03.083. 